\title{
PEMANFAATAN KAMPOENG BATJA SEBAGAI DESTINASI WISATA EDUKASI DI KABUPATEN JEMBER
}

\author{
Syah Riza Octavy Sandy \\ Dosen Akademi Pariwisata Muhammadiyah Jember \\ Email: syahrizaOS@akparmuhjember.ac.id
}

\begin{abstract}
ABSTRAK
Kabupaten Jember memiliki potensi pariwisata yang sangat menarik. Salah satu potensi yang dimiliki jember adalah wisata edukasi kampoeng batja. Kampoeng batja merupakan sarana wisata edukasi berbasis Taman Bacaan Masyarakat (TBM). Pada perkembanganya kampoeng batja berubah menjadi salah satu destinasi wisata edukasi yang sangat menarik dengan berbagai fasilitas wisata edukasi seperti rumah dongeng, sarana kreatifitas seni rupa dan origami serta sarana olahraga memanah.

Penelitian ini bertujuan untuk mengetahui sejauh mana pemanfaatan kampoeng batja sebagai sarana wisata edukasi oleh masyarakat Jember sekaligus menggali potensi wisata edukasi di Kab. Jember. Penelitian ini merupakan penelitian deskriptif kualitatif yang bertujuan untuk mendeskripsikan sebuah hasil penelitian secara sitematis tentang fakta-fakta dari pemanfaatan Kampoeng Batja. Teknik pengumpulan data dengan melakukan wawancara, penyebaran Kuesioner, Kepustakaan dan Dokumentasi. Teknik analisa data dengan cara Reduksi data, Display data dan penarikan kesimpulan.

Hasil penelitian menunjukkan bahwa kampoeng batja sudah dimanfaatkan masyarakat sebagai salah satu tujuan wisata edukasi. Hal ini ditunjukkan dari hasil observasi langsung dan tabulasi data dari kuesaioner yang disebar menunjukkan sebahagian besar masyarakat/ responden memanfaatkan kampoeng batja sebagai sarana wisata edukasi, wisata literasi, wisata kreatifitas dan wisata budaya dan mayoritas pengunjung dari kampoeng batja adalah masyarakat usia sekolah.
\end{abstract}

Kata Kunci : Wisata edukasi, tujuan wisata, wisata budaya 


\section{PENDAHULUAN}

Undang-Undang No.32 Tahun 2004

(Republik Indonesia, 2004) tentang pemerintah daerah menjadi pemicu perkembangan sector wisata daerah. Pemerintah melalui sumber daya alam dan SDM dapat mengembangkan potensi daerah sendiri yang bertujuan untuk perbaikan pendapatan daerah khusunya meningkatkan pendapatan penduduk setempat khususnya yang berada pada daerah pariwisata. Hal ini sesuai dengan UU No 10 tahun 2009 yang menyebutkan bahwa keberadaan obyek wisata disuatu daerah akan sangat menguntungkan, antara lain meningkatkan pendapatan asli daerah (PAD), meningkatkan taraf hidup masyarakat dan memperluas kesempatan kerja, meningkatkan rasa cinta lingkungan serta melestarikan alam dan budaya setempat.

Potensi pariwisata Jember yang semakin hari semakin menjadi perhatian public menjadi salah satu daya Tarik pariwisata di kabupaten Jember. Potensi pariwisata Jember yang dominan dengan wisata bahari menjadi daya tarik yang unik sehingga dominan destinasi wisata di Kab. Jember adalah pantai dan fasilitas disekitarnya. Selain itu event tahunan yang paling banyak menyita perhatian public dan menarik wisatawan asing maupun local adalah Jember Fashion Carnival yang di gagas oleh Dynand Fariz seorang putra Jember yang mendedikasikan dirinya menjadi Prseden JFC Sebagai Ikon Karnaval dunia di Jember.

Selain potensi wisata bahari dan event tahunan JFC yang menjadi daya tarik wisatawan lokal dan mancanegara, jember juga memiliki banyak destinasi wisata edukasi yang mungkin belum menjadi destinasi favorit. Salah satunya adalah kampoeng batja, yang merupakan sebuah perpustakaan pribadi yang dikelola dengan apik oleh sang pemilik. Kampoeng batja merupakan sarana wisata edukasi khususnya untuk anak usia pendidikan dini yang berfokus pada pengenalan literasi, kreatifitas dan peningkatan minat baca khususnya bagi anak usia sekolah dasar.

Kampoeng batja merupakan perpustakaan, gallery dan wahana edukasi yang memadukan konsep perpustakaan dan tempat belajar. Mengedepankan fungsi perpustakaan sebagai tempat rekreasi, tempat ini menyediakan fasilitas literasi informasi berupa buku dan karya cipta lainnya termasuk didalamnya beberapa karya seni.

\section{TUJUAN DAN JENIS PENELITIAN}

Penelitaian ini bertujuan untuk mengetahui pemanfaatan kampoeng batja sebagai sarana rekserasi edukasi khususnya bagi masyarakat jember. Tujuan lain adalah untuk menggali potensi pariwisata edukasi yang dimiliki kampoeng batja. Penelitian ini merupakan penelitian deskriptif kualitatif yang bertujuan untuk mendeskripsikan sebuah hasil penelitian secara sitematis tentang fakta-fakta dan sifat dari suatu populasi atau objek tertentu. Penelitian ini akan mendeskripsikan kondisi objek penelitian melalui survey dan observasi . Menurut Raco (2010) ciri khas penelitian kualitatif adalah penekanannya pada proses, yang dimaksud adalah meliha bagaimana data dan fakta terjadi secara alami.

\section{KAJIAN TEORITIS}

Terciptanya sebuah kondisi pariwisata tentu memiliki komponenkomponen yang harus dipenuhi. Menurut I gede Pitana (Pitanan, 2012) dalam seminar Cooperation in the Development of Education and Tourism in Global Era menyebutkan bahwa destinasi wisata hendaknya memiliki 4 komponen utama yaitu 
a. Atraksi

Daya tarik wisata dapat berupa konsisi alam seperti pantai, air terjun atau juga wisata buatan manusia seperti bangunan bersejarah dan juga dapat berwujud pariwisata seperti sebuah festival atau pertunjukan.

b. Aksesibilitas

Kemudahan akses dalam mencapai tujuan wisata termasuk didalamnya fasilitas transportasi, lama waktu yang dibutuhkan untuk mencapai daerah tujuan .

c. Amenities

Amenities adalah segala fasilitas pendukung yang bias memnuhi kebutuhan dan keinginan wisatawan selama berada di destinasi. Amenitas berkaitan dengan ketersediaan sarana akomodasi untuk menginap serta restoran atau warung makan dan minuman. Kebutuhan lain yang mungkin juga dibutuhkan adalah toilet umum, rest area, tempat parker dan sarana publik lainnya.

d. Ancilliary

Ancilliary merupak ketersediaan sebuah organisasi atau orang -orang yang mengurus destinasi tersebut. Ini menjadi penting karena walaupun destinasi sudah mempunyai atraksi aksesibilitas dan amenitas, jika kesemua fasilitas tidak dikelola dengan baik maka sumber daya pariwisata akan terbengkalai dan sia sia.

Untuk dapat menjadi sebuah daerah tujuan wisata pengelola wisata sudah seharusnya memperhatikan komponen wisata tersebut sehingga satu kesatuan kebutuhan wisatawan saat melakukan perjalanan wisata dapat terpenuhi.

Menurut WATA (World Associato of Travel Agent) wisata adalah perjalanan keliling selama lebih dari tiga hari yang diselenggarakan oleh suatu kantor perjalanan di dalam kota dan acaranya antara lain melihat-lihat diberbagai tempat atau kota baik didalam maupun luar negri. Menurut Rodger dalam Ratih (R., 2014) Wisata edukasi atau yang lebih popular dengan sebutan edutourism merupakan suatu program wisata dimana wisatawan berkunjung ke sebuah objek wisata dengan tujuan utama untuk memperoleh pengalaman pembelajaran secara langsung dari obyek wisata tersebut.

Dalam UU RI No 10 TAHUN 2009 tentang kepariwisataan disebutkan bahwa wisata adalah kegiatan perjalanan yang dilakukan oleh seeorang atau sekelompok orang dengan mengunjungi tempat tertentu untuk tujan rekreasi, pengembangan pribadi atau mempelajari keunikan daya tarik wisata yang dikunjungi dalam jangka waktu sementara. Sedangkan orang yang melakukan wisata disebut wisatawan. (Republik Indonesia, 2009)

Kegiatan dalam pariwisata ini sangat ditentukan oleh minat wisatawan dan sumber daya pariwisata yang tersedia. Jika perjalanan dilakuakn untuk melihat objek sejarah maka kegiatan ini sering disebut wisata sejarah, jika dilakukan untuk mendukung kegiatan belajar maka akan disebut wisata edukasi. Jika wisata dilakukan dalam hal meningkatkan pengetahuan tentang bercocok tanam dan sejenisnya akan disebut sebagai wisata agro begitu juga jika dilakukan untuk ibadah maka wisata akan disebut sebagai wisata Religi.

Wisata edukasi ilmu pengetahuan saat ini banyak dikembangkan di Indonesia. Wisata ini bertujuan untuk mendukung proses kegiatan belajar mengajar yang sudah diterima para siswa di lembaga pendidikan formal. Wisata edukasi berbasis perpustakaan merupakan salah satu bentuk wisata edukasi yang seharusnya dikembangkan. Perpustakaan sebagai pusat belajar mandiri dapat dijadikan sarana 
rekreasi bagi seluruh masyarakat. Keberadaan perpustakaan sebagai sarana publik menjadi daya tarik tersendiri untuk dapat dikembagkan sebagai wahana wisata edukasi. Namun pada kenyataannya banyak perpusatakaan milik pemerintah yang belum dapat menyediakan perpustakaan sebagai sarana rekreasi dan belajar dalam satu kesatuan.

\section{PEMANFAATAN KAMPOENG BATJA SEBAGAI SARANA WISATA EDUKASI}

Kampoeng Batja sebagai sarana wisata edukasi tidak dapat dipungkiri sangat berpotensi untuk dijadikan sarana wisata edukasi. Jika melihat syarat untuk menjadi sebuat tujuan wisata Kampoeng batja sudah memili komponen pariwisata. Kampoeng batja memiliki komponen Atraksi terlihat dari beberapa fasilitas yang dimilikinya seperti wahana belajar, berkreasi, wahana mendongeng dan wahana memanah. Jika dinilai dari Aksesibilitas Kampoeng batja sangat mudah diakses karena berada tepat di kota Jember tidak jauh dari Alun-Alun kota yang merupakan jantung kota jember. Tempat ini sangat mudah diakses baik dengan kendaraan umum maupun kendaraan pribadi. Amenities yang merupakan sarana pendukung seperti akomodasi juga dimiliki kampoeng batja. Saat ini kampoeng batja memiliki musholla untuk kegiatan beribadah, memiliki toilet umum dan sebuah penginapan minimalis yang dapat menampung masyarakat yang ingin menginap, potensi lain adalah bahwa tempat ini tidak jauh dari berbagai fasilitas publik seperti hotel dan jalan raya. Dari sisi Ancillary atau ketersediaan organisasi atau orang yang mengelola destinasi wisata tentu saja dimiliki oleh kampoeng Batja. Kampoeng Batja dikelola secara kekeluargaan oleh sang pemilik yaitu Bapak Iman Suligi yang merupakan seorang pensiunan guru, penggiat literasi dan seniman yang memadukan kesemua komponen tersebut sehingga kampoeng batja menjadi sebuah destinasi wisata edukasi yang sangat komplit di tengah kota Jember.

1. Pemanfaatan Kampoeng Batja

a. Persepsi masyarakat terhadap pemanfaatan kampoeng batja sebagai tujuan wisata edukasi.

Persepsi masyarakat terhadap pemanfaatan kampeng batja sebagai sarana wisata edukasi terlihat dari data berikut:

Tabel 6. Persepsi masyarakat terhadap pemanfaatan Kampoeng Batja

\begin{tabular}{|l|l|l|l|}
\hline No & Sikap & Jumlah & Presentasi \\
\hline 1 & Sangat Setuju & 8 & $16 \%$ \\
\hline 2 & Setuju & 41 & $82 \%$ \\
\hline 3 & Ragu-ragu & 1 & $2 \%$ \\
\hline 4 & Tidak setuju & 0 & $0 \%$ \\
\hline 5 & $\begin{array}{l}\text { Sangat Tidak } \\
\text { Setuju }\end{array}$ & 0 & $0 \%$ \\
\hline & & & \\
\hline
\end{tabular}

Data diatas menunjukkan bahwa sebahagian besar responden 41 orang (82\%) menyatakan setuju jika Kampoeng Batja dijadikan sarana wisata edukasi. Dan tidak ada satu orangpun responden yang tidak setuju.

b. Pemanfaatan Fasilitas Kampoeng Batja secara Keseluruhan

Pemanfaatan kapoeng batja sebagai salah satu destinasi wisata edukasi oleh masyarakat Jember dan sekitarnya sudah tidak diragukan lagi. Fakta dilapangan berupa hasil observasi pada saat survey mendeskripsikan bahwa kegiatan wisata edukasi di kampoeng batja sangat diminati masyarakat secara nyata terlihat dari tingkat kunjungan wisatawan yang konsisten setiap harinya, bahkan cenderung meningkat. Berikut persepsi masyarakat 
terhadap fasilitas edukasi yang dimiliki Kampeng batja:

Tabel 5. Persepsi Masyarakat Terhadap Fasilitas Edukasi

\begin{tabular}{|l|l|l|l|}
\hline No & Sikap & Jumlah & Persentase \\
\hline 1. & Sangat setuju & 5 & $10 \%$ \\
\hline 2. & Setuju & 43 & $86 \%$ \\
\hline 3. & Ragu-Ragu & 2 & $4 \%$ \\
\hline 4. & Tidak Setuju & 0 & $0 \%$ \\
\hline 5 & $\begin{array}{l}\text { Sangat Tidak } \\
\text { Setuju }\end{array}$ & 0 & $0 \%$ \\
\hline & Juplabed_diatas & $50_{\text {nuniuk100\% }}$ 16ahwa \\
\hline
\end{tabular}

43 responden atau sebesar $86 \%$ responden menyatakan setuju bahwa fasilitas yang dimiliki Kampoeng Batja sebagai sarana wisata edukasi sangat memadai, bahkan 5 orang responden atau sebesar $10 \%$ menyatakan sangat setuju. Walaupun ada 2 responden atau $4 \%$ yang menyatakan raguragu. Alasan responden yang menyatakan ragu- ragu dikarenakan akses ke kampoeng batja yang sedikit bermasalah karena tidak dapat diakses oleh kendaraan roda 4, hal ini dikarenakan kampoeng batja berada di tengah pemukiman padat penduduk sehingga tidak tersedia lahan parkir yang memadai.

c. Pemanfaatan Kampeong Batja sebagai wisata literasi

Wisata literasi Informasi merupakan kegiatan wisata yang dihubungkan dengan kegiatan literasi seperti membaca, mencari informasi dan memanfaatkan informasi tersebut. Kampoegn batja sebagai TBM menyediakan banyak koleksi perpustakaan termasuk koleksi dalam bentuk kolase dan ...... Koleksi ini merupakan salah satu andalam di Kampoeng batja dan tentu saja dapat meningkatkan keingintahuan pengunjung dengan cara membaca atau berdiskusi dengan pemilik. Untuk mengetahui pemanfaatan kampoeng batja sebagai wisata literasi berikut hasil data yang telah diolah dari questioner dan wawancara yang telah dilakukan:

Tabel 6. Pemanfaatan Kampoeng Batja sebagai wisata literasi

\begin{tabular}{|l|l|l|l|}
\hline No & Sikap & Jumlah & Persentase \\
\hline 1 & Sangat setuju & 42 & $84 \%$ \\
\hline 2 & setuju & 8 & $16 \%$ \\
\hline 3 & Ragu-Ragu & 0 & 0 \\
\hline 4 & Tidak Setuju & 0 & 0 \\
\hline 5 & $\begin{array}{l}\text { Sangat tidak } \\
\text { setuju }\end{array}$ & 0 & 0 \\
\hline & J balah diatas ménunjumkan bahwa \\
\hline
\end{tabular}

hampir seluruh responden atau sebanyak 42 orang (84\%) menyatakan sangat setuju kampoeng batja dimanfaatkan sebagai tujuan wisata literasi informasi dan tidak ada responden yang tidak setuju bahkan ragu-ragu dengan statemen ini.

d. Pemanfaatan Kampoeng Batja untuk pengembangan kreatifitas Kegiatan pengembangan kreatifitas di kampoeng batja terlihat dari banyaknya kegiatan pengembangan kreatifitas yang dapat dilakukan dan disediakan di kampoeng batja. Diantaranya adalah kegiatan origami dan seni rupa. Kegiatan ini merupakan salah satu kegiatan yang banyak diminati pengunjung. Persepsi masyarakat terhadap pemanfaatan kampoeng batja sebagai sarana pengembangan kreatifitas dapat dilihat pada table berikut: 
Tabel 7. Pemanfaatan Kampoeng Batja untuk pengembangan kreatifitas

\begin{tabular}{|l|l|l|l|}
\hline No & Sikap & Jumlah & Persentase \\
\hline 1 & Sanagat setuju & 48 & $96 \%$ \\
\hline 2 & Setuju & 2 & $4 \%$ \\
\hline 3 & Ragu-ragu & 0 & $0 \%$ \\
\hline 4 & Tidak Setuju & 0 & $0 \%$ \\
\hline 5 & $\begin{array}{l}\text { Sangat Tidak } \\
\text { Setuju }\end{array}$ & 0 & $0 \%$ \\
\hline & Jumlah & 50 & $100 \%$ \\
\hline
\end{tabular}

Data diatas menunjukkan bahwa responden sangat setuju dengat statement pemanfaatan kampoeng batja untuk pengembangan kreatifitas. Sikap sangat setuju terhadap pemanfaatan kampoeng batja sebagai sarana pengembangan kreatifitas mencapai $96 \%$ atau sebanyak 48 responden dikarenakan kegitan pengembangan kreatifitas yang disediakan Kampoeng Batja benarbenar dirasakan bermanfaat oleh para pengunjung terutama orang tua yang mendampingi buah hatinya atu guru sebagai pendamping kegiatan yang dilakukan di kampoeng batja.

e. Pemanfaatan kampoeng batja sebagai wisata budaya

Selain wisata literasi, pengunjung kampoeng batja juga dapat menikmati wisata budaya yang disugguhkan dalam balutan pagelaran seperti pagelaran wayang dan rumah dongeng. Selain itu benda-benda kesenian juga dipanjang di beberapa sudut kampoeng batja sebagai sarana untuk memperkenalkan budaya Indonesia yang merupakan warisan nenek moyang yang patutu dilestarikan dan diperkenalkan khususnya kepada generasi muda khususnya pelajar yang menjadi pengunjung dominan kampoeng batja.

Untuk mengetahui tingkat pemanfaatan kampoeng batja sebagai sara wisata budaya, berikut data yang dihimpun dari responden:

Tabel 8. Pemanfaatan Kampoeng batja sebagai saran wisata budaya

\begin{tabular}{|c|c|c|c|}
\hline No & Sikap & Jumlah & Presentase \\
\hline 1 & Sangat Setuju & 12 & $24 \%$ \\
\hline 2 & Setuju & 36 & $72 \%$ \\
\hline 3 & Ragu-ragu & 2 & $4 \%$ \\
\hline 4 & Tidak Setuju & 0 & $0 \%$ \\
\hline 5 & $\begin{array}{ll}\text { Sangat } & \text { Tidak } \\
\text { Setuju } & \end{array}$ & 0 & $0 \%$ \\
\hline & Jumlah & 50 & $100 \%$ \\
\hline
\end{tabular}

sebanyak 36 orang responden atau sebesar $72 \%$ menyatakan setuju kampoeng batja sebagai sarana wisata budaya. 12 orang atau $24 \%$ responden menyatakan samgat setuju dan hanya 2 oranga responden yang menyatakan raguragu.

2. Saran Untuk Pengembangan Kampoeng Batja

Persepsi masyarakat terhadap upaya pengembangan kampoeng batja sebagai tujuan wisata edukasi seharusnya menjadi sorotan utama oleh pemilik kampoeng batja. Status kepemilikan kampoeng batja yang merupakan milik pribadi menjadi salah satu kendala dalam pengembangan, mengingat sang pemilik merupakan seorang pensiunan dan hampir sebahagian besar layanan wisata edukasi yang ada di kampoeng batja dapat dinikmati dengan membayar seikhlasnya bahkan gratis. Namun komitmen pemilik kampoeng batja untuk mengembangkan potensi kampoeng batja terutama sarana fisik terus dilakukan. Melalui penghargaan 
yang sering diterima pemilik kampoeng batja dalam event berskala daerah maupun nasional banyak menggugah para donator untuk pengembangan kampoeng batja walaupun tidak terlihat signifikan.

Salah satu sarana untuk mengembangkan potensi kampoeng batja adalah dengan memberikan saransaran untuk kemajuan kedepan. Berdasarkkan kuesioner yang disebarkan berikut adalah beberapa saran untuk pengembangan kampoeng batja sebagai sarana wisata edukasi.antara lain:
a. Perbaikan ketersediaan lahan parkir
b. Peningkatan publikasi dan promosi kampoeng batja
c. Pengembangan lahan.

\section{KESIMPULAN}

Kampoeng Batja merupakan salah satu potensi wisata edukasi yang harus diperhatikan dan didukung oleh pemerintah. Keberadaan kampoeng batja sebagai sarana wisata edukasi sangat membantu pemerintah dalam mencerdaskan anak bangsa. Kampoeng Batja memiliki potensi wisata edukasi yang berfariasi, mulai dari wisata literasi, wisata budaya dan wisata kreatifitas. Selain wisata literasi kampoeng batja juga menyediakan sarana olah raga memanah baik untuk anak - anak, remaja dan dewasa. Potensi fisik, potensi budaya dan potensi pendidikan kampoeng batja diharapkan dapat terus dikembangkan sehingga dapat memenuhi kebutuhan wisata edukasi masyarakat Jember.Perhatian pemerintah sangat dibutuhkan untuk pengembangan sarana dan prasarana Kampoeng Batja.

\section{DAFTAR PUSTAKA}

Basuki, S. (2010). Pengantar Ilmu Perpustakaan. Jakarta : Gramedia.

Emzir. (2010). Metodologi Penelitian Kualitatif Analisis Data. Jakarta : Rajawali Press.

Pitanan, I. G. (2012). Cooperation in the Development of Education and Tourism in Global Era. Surabaya: s.n.

R., N. R. (2014). Perancangan Wisata Edukasi Lingkungan Hidup. Malang: Universitas Brawijaya.

Republik Indonesia. (2004). Undang Undang No 32 Tahun 2004. JAKARTA: Kementrian Dalam negri. Republik Indonesia. (2007). UndangUndang No 23 Tahun 2007 . Jakarta: Kementrian Pendidikan.

Republik Indonesia. (2009). Undang Undang RI NO 10 Tahun 2009. Jakarta : Departemen Kebudayaan dan

Pariwisata. 